\title{
THE PROMOTION OF CROSS-CURRICULAR PROBLEM SOLVING ABILITIES OF PRE-SERVICE SCIENCE TEACHERS THROUGH COOPERATIVE LEARNING
}

\author{
Palmira Peciuliauskiene \\ Dalius Dapkus \\ Lithuanian University of Educational Sciences, Lithuania
}

\begin{abstract}
Inquiry-based science teaching (IBST) can be realized with a help of different educational technologies. An educational project carried out at Lithuanian University of Educational Sciences used a framework of cross-curricular (biology, chemistry and physics) learning content, learning concepts (learning through cooperation, PBL) and learning method (a nine phase cycle of project activities with self-evaluation at the end of each phase). A case study of application of cross-curricular relationships while teaching pre-service science (biology, chemistry and physics) teachers at Lithuanian University of Educational Sciences was carried out. Quantitative and qualitative methods were used, together with observation of activities of 120 respondents (pre-service teachers) in learning through cooperation. The results revealed that PBL based on cross-curricular content provided suitable conditions for reaching higher levels of problem solving abilities.
\end{abstract}

Keywords: problem-based learning, problem solving abilities, cross-curricular content, cooperative learning.

\section{Introduction}

The development of society in the $21^{\text {st }}$ century requires a new creative class. Creativity is an important feature of society, and is disclosed through the generation of new ideas, adaptation to changing situations, and solutions to problems (EC, 2010). Problems can be solved while working individually or in groups. The ability to create new intellectual products while working in cooperation is important in the creative society (Florida \& Tinagli, 2004). Labour market experts, managers of human resources, and vocational education and training experts find these abilities to be essential. A 2010 Euro barometer survey of 31 European countries showed that $67 \%$ of leaders in the business and public sectors highly valued employees' team working abilities, whilst these employers also thought that analytical skills, problem solving and adaptation to new situations were important.

There are still, however, significant obstacles to the measurement of collaborative tasks within large-scale international surveys such as PISA (Reeff, Zabal \& Blech, 2006). The PISA results suggest that it is necessary to pay attention to problem solving abilities, as, on average in OECD countries, half the students were unable to solve anything other than basic problems (PISA, 2003; 2012). 
In inquiry-based science teaching (IBST), a teacher begins not with a statement but with a problem. PBL is an effective method of instruction in many areas, and employs open-ended questions that are not limited to a single correct answer. Questions elicit diverse ideas and opinions, and require students to work as a group (Kim, Hannafin \& Bryan, 2007; Zion, 2008).

IBST engages students in authentic and problem based learning activities where there may not be a correct answer. Cross-curricular problems often involve multiple goals, which are in conflict amongst each other, as progress towards one may detract from progress towards the other(s). Learning through cooperation can help in solving cross-curricular problems. Elaboration and weighing of priorities is required for the problem solver to achieve a balance between the goals (Blech \& Funke, 2010; Brown, Harris \& Russell, 2010). Cross-curricular problems are frequently ill-defined (Mayer \& Wittrock, 2006).

The use of PBL based on cross-curricular content requires the shift of knowledge from one subject to another in each cross-curricular teaching situation (horizontal shift). This shift provides a new character, creates problem situations, and encourages the acquisition of new information or reveals new aspects of the knowledge acquired (Funke, 1991; Edelson, 2001).

Solving cross-curricular problems also creates favourable conditions for the improvement of general, subject and cross-curricular abilities. Problem solving as cognitive processing is directed at transforming a given situation into a goaloriented situation where no obvious solution is available (Mayer, 2006). These generic abilities are best developed when they are drawn on intentionally, but they should not be taught in isolation from any program content. They are a joint responsibility and require shared planning so that all of them receive sufficient attention (Barnes, 2011; PISA, 2012).

The evaluation and self-evaluation are important parts of PBL. Many researchers have investigated the evaluation of problem solving abilities (Blench \& Funke, 2010; Greiff \& Funke, 2008; Leutner, Klieme, Meyer, \& Wirth, 2004; Osman, 2010). However, there is a lack of research about the role of evaluation and self-evaluation in PBL (Scott, 2014).

Learning through cooperation, problem based learning and use of crosscurricular relationships are common, but insights into the application of these models in educational practice, especially while training pre-service teachers, are still lacking.

The mentioned aspects of problem based learning have led to the problems: what are cross-curricular problem solving abilities of pre-service teachers? How does learning through cooperation influence cross-curricular problem solving abilities?

The objectives: to disclose the cross-curricular problem solving abilities of pre-service science teachers and to reveal the role of collaboration in the promotion of problem solving abilities. 


\section{Theoretical background}

Constructivism provides a methodological background of IBST that can be realized by using different learning practices, such as discovery learning (Anthony, 1973), problem based learning (PBL) (Schmidt, 1983), inquiry learning (Papert, 1980), experiential learning (Boud, Keogh \& Walker, 1985) or constructivist learning (Steffe \& Gale, 1995) These practices are based on constructivism (Kirschner, Sweller \& Clark, 2006), who suggest that learning based on constructivism can be called both problem-based learning and inquirybased learning.

The theoretical background of PBL can be found in the pragmatism philosophy of J. Dewey at the beginning of the $20^{\text {th }}$ century. In his books Experience and Nature (Dewey, 1925) and The Quest for Certainty (Dewey, 1929), J. Dewey rejected the theory of cognition which holds that a person is an observer of the world. According to him, the person fights for survival while solving problems. K. Duncker (1945) tried to describe problem situations by saying that a problem exists when a person has a goal but does not know how to achieve it. P. Frensch and J. Funke (1995) created a model of the problem situation (Fig. 1). According to the model, the 'given' is the knowledge that a person has about the problem. The 'operators' are the admissible actions that can be performed to achieve the desired goal state (outcomes) with the assistance of the available tools. It is necessary to overcome barriers between experience acquired and new cognition in every problem situation.

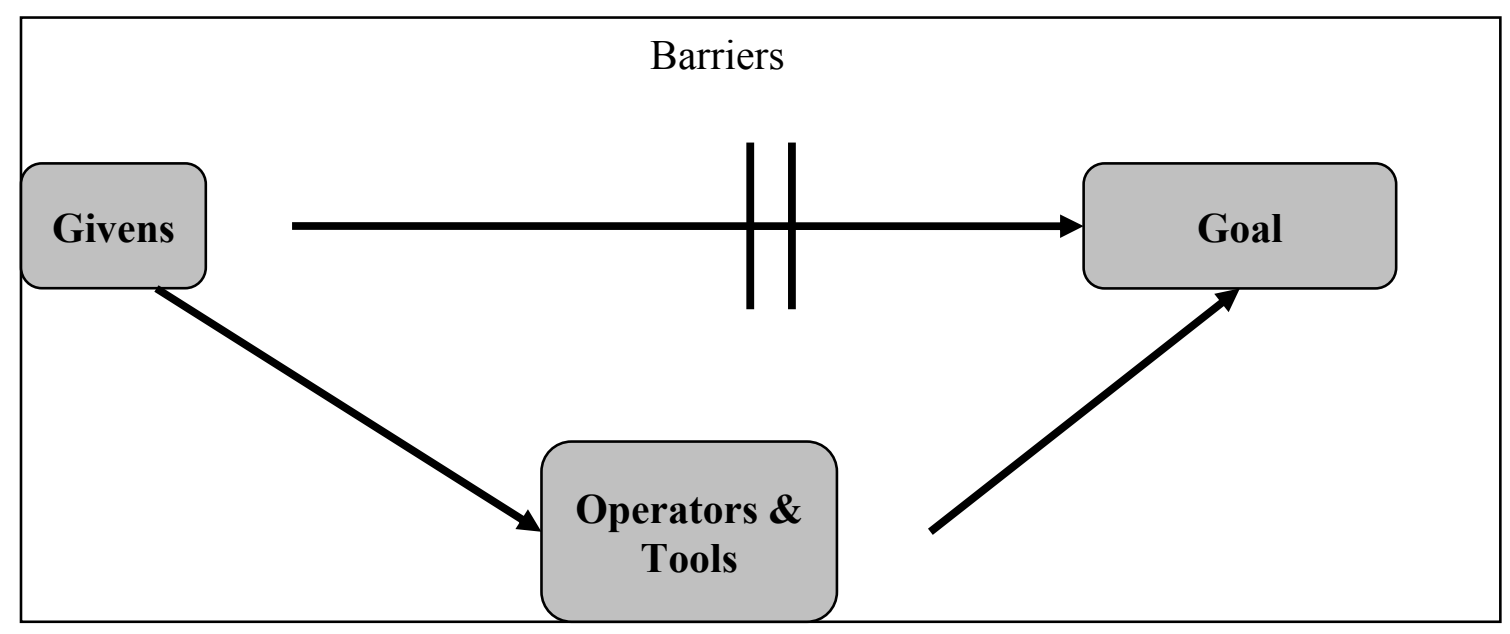

Fig. 1. Problem situation model (according to Frensch \& Funke, 1995)

We supplemented the model of P. Frensch and J. Funke (1995) and adjusted it to PBL in our activities (Fig. 2). The givens are composed of the content of physics, chemistry and biology, while the goal consists of general (communication, ability to learn, and cognition), subject and cross-curricular abilities. The group of operators and tools consists of two subsets: curriculum and social operators. 


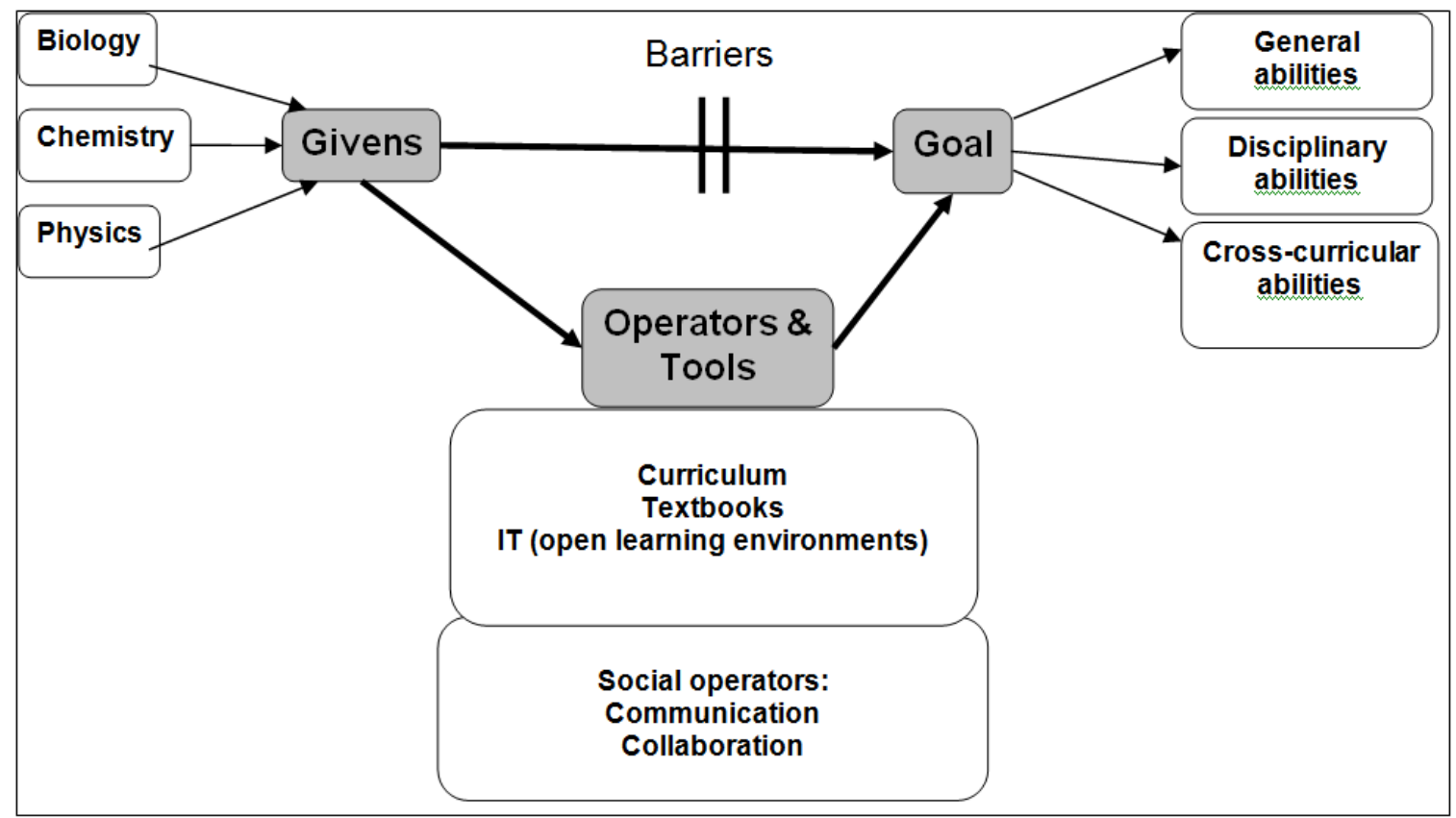

Fig. 2. Learning model based on cross-curricular content applied at Lithuanian University of Educational Sciences

Cross-curricular content determines social interaction (Fig. 2). Crosscurricular links among the content of different disciplines have a subjective character. The search for cross-curricular relationships is an active process in which individual students can interpret connections between facts, and can find specific relationships between the content of biology, chemistry and physics. This diversity of links is easily disclosed when the same project is implemented in a group of students studying different science programs. The diversity of cross-curricular relationships therefore enhances aspects of learning through cooperation, including the ability to achieve a single solution, and the ability to choose similar models of cross-curricular relationships and problem solving scenarios.

Cross-curricular educators, however, have little information about how to implement problem-based learning in classrooms where multiple disciplines are represented (Keebaugh, Darrow, Tan \& Jamerson, 2009). Gaps in knowledge may be filled by observation and exploration of the problem situation. This often involves interaction with a new system to discover rules that in turn must be applied to solve the problem.

\section{Methodology}

Method of research. A case study of application of cross-curricular relationships while teaching pre-service science (biology, chemistry and physics) teachers at Lithuanian University of Educational Sciences was carried out. Quantitative (questionnaires) and qualitative (semi-structured interview) 
methods were used together of activities of the pre-service teachers in learning through cooperation.

A project carried out at Lithuanian University of Educational Sciences combined learning content (cross-curricular content [biology, chemistry and physics]), learning concepts (learning through cooperation, PBL) and a learning method proposed by Foldevi (1995). According to the method, the learning cycle is composed of nine phases: 1) Creating scenarios for a problem situation; 2) Creation of a group plan; 3) Formulation of a hypothesis for finding a solution to the problem; 4) Brain storming; 5) Definition of the problem; 6) Formulation of learning tasks; 7) Deepening one's knowledge; 8) Discussions and careful research of knowledge; 9) Application of knowledge in practice. The self-evaluation of abilities is performed at the end of each learning phase.

We extended M. Foldevi's method by applying it not just to students of a single subject but also to cross-curricular content of different science subjects (biology, chemistry and physics). In order to provide favourable conditions for learning through cooperation, the time schedule of subject didactics seminars for pre-service teachers studying different subject programs was synchronised. Heterogenous groups studying different science subjects were formed. They implemented one cross-curricular project in two seminars (four hours in all) on subject didactics. They also worked independently (for three hours) between the two seminars.

Each group worked exclusively on cross-curricular problems within shortterm projects. They had to create models of cross-curricular relationships, predict possible links and suggest methods for their analysis during lectures. For example, they had to present the theme "Atmosphere: its physical and chemical aspects". From the point of view of chemistry, it was important to disclose the structure of atmosphere, the formation of oxygen and oxidation of metals. From the point of view of biology and physics, pre-service teachers had to disclose the importance of oxygen to life (photosynthesis, respiration, etc.), as well as the formation of atmosphere and its layers, etc.

IBST is characterized by a variety of levels. We referred to the theory of $\mathrm{H}$. Banchi \& R. Bell (2008) when deciding how to teach pre-service teachers. The highest level (open inquiry) is reached when learners identify a problem, methods for its solution, and explanations for the cross-curricular phenomena themselves. Therefore, the method proposed by M. Foldevi corresponds to open inquiry, as its six phases are devoted to the search for solutions to problems.

The instrument of quantitative research. We used the PISA (2012 instruments) for the evaluation of problem solving abilities. They are reliable and valid.

The sample of quantitative research. The respondents were 120 pre-service science teachers, comprising two thirds of third and fourth year science students studying at Lithuanian University of Educational Sciences. 
The sample of qualitative research. A semi-structured interview, based on methodology PISA (2012) revealed the attitude of pre-services teachers towards the PBL. The sample of the qualitative research was purposive modal instance sampling (Patton, 2002). A qualitative study was conducted with 40 pre-services teachers.

\section{Results \\ The results of qualitative analysis}

We used the methodology of the PISA (2012) field trial problem-solving framework in order to assess the attitudes of pre-service teachers towards problem solving abilities and their self-evaluation. The methodology describes levels and criteria for problem solving abilities. At least four levels of proficiency can be identified in showing how problem-solving abilities grows and develops (PISA, 2012). We used these levels to highlight differences between strong and weak problem solving abilities (Table 1).

Table 1. Four levels of proficiency of problem solving abilities of pre-service science teachers

\begin{tabular}{|l|l|}
\hline High ability criteria & Low ability criteria \\
\hline $\begin{array}{l}\text { 1. Able to plan and execute solutions that } \\
\text { involve a relatively high number of steps }\end{array}$ & $\begin{array}{l}\text { 1. Able to plan and execute solutions that } \\
\text { involve only a few steps and simple } \\
\text { reasoning }\end{array}$ \\
\hline $\begin{array}{l}\text { 2. Able to understand and relate } \\
\text { information presented in a variety of } \\
\text { familiar or unfamiliar representations }\end{array}$ & $\begin{array}{l}\text { 2. Able to understand or to relate } \\
\text { information only between familiar } \\
\text { representations }\end{array}$ \\
\hline $\begin{array}{l}\text { 3. Able to deal with situations involving } \\
\text { many variables where there is high } \\
\text { dependency between the variables }\end{array}$ & $\begin{array}{l}\text { 3. Able to solving a problem unless it } \\
\text { involves only one or two variables with } \\
\text { limited dependency }\end{array}$ \\
\hline $\begin{array}{l}\text { 4. Able to discover undisclosed } \\
\text { information or handle unanticipated } \\
\text { obstacles }\end{array}$ & $\begin{array}{l}\text { 4. Able to discover undisclosed } \\
\text { information if instructions are provided to } \\
\text { direct exploration activity }\end{array}$ \\
\hline
\end{tabular}

Levels of problem solving abilities are defined according to these activities are planning and execution of solutions, understanding and relating information, dealing with situations, and handling unanticipated obstacles (Table 1).

According to PISA (2012), problem-solving abilities depend on the content of a particular activity, e.g. planning and execution of solutions that involve a relatively high number of steps (high ability criteria), and planning and execution of solutions that involve only a few steps and simple reasoning (low ability).

The answers of the pre-service science teachers revealed that PBL based on cross-curricular content provided suitable conditions for reaching higher levels 
of problem solving abilities, that were not limited by only a few steps and simple reasoning „Implementation of a project is constantly related with thinking how to explain a phenomenon from the point of view of physics, chemistry and biology. It is easier for me to analyze a problem from the point of view of physics. The latter tasks are more understandable and it is not necessary to go deep into them".

PBL on the basis of cross-curricular content promotes understanding and discovering of new information. Cross-curricular projects change attitude towards sources of information and the Internet: "Searching for subject information is an easy task. It is necessary to write the keyword and you get what you want. Therefore, it is not suitable for implementing cross-curricular projects. There is a problem regarding keywords and cross-curricular relationships that should be found by ourselves."

In summary, PBL on the basis of cross-curricular content creates suitable conditions for the improvement of problem solving abilities, as cross-curricular content involves a relatively high number of steps, promotes the processes of dealing with situations involving many variables, and helps in discovering undisclosed information.

The answers of the pre-service teachers disclosed that solving of crosscurricular problems through learning in cooperation made the self-evaluation of activities complicated. It was obvious that the pre-service science teachers knew the contents of their own individual subject (biology, chemistry or physics), but that they lacked broader understanding of other science subjects. For example, a student studying physics at university level lacks knowledge regarding chemistry and biology. Therefore, only cooperative work with other students can overcome that problem and the implementation of cross-curricular projects becomes possible.

\section{The results of quantitative analysis}

The construct validity of our quantitative research was ensured by the use of the PISA field trial problem-solving framework (PISA, 2012). Construct validity requires the use of the correct measures for the concepts being studied. Problem solving abilities were our main concept, made up of exploring and understanding, representing and formulating, planning and executing, monitoring and reflecting. These abilities are formed at different phases in the Foldevi's methodology (Table 2).

According to the PISA (2012) criteria for problem solving evaluation, the pre-service science teachers self-evaluated their own abilities, as well as problem solving abilities of other members working in the same group.

We distinguished two stages of self-evaluation. The first stage was performed after finishing a short-term cross-curricular project, while the second was carried out at the end of the didactics course, with all short-term projects 
already finished. The student teachers evaluated problem solving abilities in cross-curricular projects by using a three-grade scale: "excellent", "well", and "weakly". The same scale of evaluation was applied at the beginning and end of the project (Table 3 ).

Table 2. The problems solving abilities (from PISA 2012 field trial problem solving framework) at different phases of Foldevi's method

\begin{tabular}{|c|c|c|}
\hline $\begin{array}{l}\text { Problem solving } \\
\text { abilities }\end{array}$ & $\begin{array}{l}\text { Phases of } \\
\text { Foldevi's } \\
\text { methodology }\end{array}$ & Evaluation criteria of problem solving abilities \\
\hline \multirow[t]{2}{*}{$\begin{array}{l}\text { Exploring and } \\
\text { understanding }\end{array}$} & \multirow[t]{2}{*}{$1 ; 2 ; 4 ; 5$} & $\begin{array}{l}\text { Exploring the problem situation (observing; } \\
\text { searching for information; finding obstacles). }\end{array}$ \\
\hline & & $\begin{array}{l}\text { Understandinggiven and discovered information, } \\
\text { demonstrating understanding of relevant concepts. }\end{array}$ \\
\hline \multirow[t]{2}{*}{$\begin{array}{l}\text { Formulating and } \\
\text { representing }\end{array}$} & \multirow[t]{2}{*}{3 and 7} & $\begin{array}{l}\text { Formulating hypotheses, organising and critically } \\
\text { evaluating information. }\end{array}$ \\
\hline & & $\begin{array}{l}\text { Representing the problem by graphical, tabular, } \\
\text { symbolic or verbal representations. }\end{array}$ \\
\hline \multirow[t]{2}{*}{$\begin{array}{l}\text { Planning and } \\
\text { executing }\end{array}$} & \multirow[t]{2}{*}{$6 ; 8 ; 9$} & $\begin{array}{l}\text { Planning of goal setting, devising a plan or strategy } \\
\text { to reach the goal state, including the steps to be } \\
\text { undertaken. }\end{array}$ \\
\hline & & Executing a plan of problem solving \\
\hline \multirow[t]{2}{*}{$\begin{array}{l}\text { Monitoring } \\
\text { and reflecting }\end{array}$} & \multirow[t]{2}{*}{$1-9$} & $\begin{array}{l}\text { Monitoring of intermediate and final results, } \\
\text { detecting unexpected events. }\end{array}$ \\
\hline & & $\begin{array}{l}\text { Reflecting on solutions, critically evaluating } \\
\text { alternative solutions, looking for additional } \\
\text { information or clarification of the goals. }\end{array}$ \\
\hline
\end{tabular}

Table 3. Self-evaluation of problem solving abilities of pre-service science teachers (percentage frequency in the first and the second diagnostic studies)

\begin{tabular}{|l|c|l|l|l|l|c|}
\hline $\begin{array}{l}\text { The abilities } \\
\text { of problem } \\
\text { solving } \\
\text { competency }\end{array}$ & \multicolumn{2}{|l|}{ First diagnostic study (grades) } & \multicolumn{2}{l|}{ Second diagnostic study (grades) } \\
\cline { 2 - 7 } & Excellent & Well & Weakly & Excellent & Well & Weakly \\
\hline $\begin{array}{l}\text { Exploring } \\
\text { Understanding }\end{array}$ & 35.6 & 51.3 & 13.1 & 38.2 & 47.8 & 14.0 \\
\cline { 2 - 7 } $\begin{array}{l}\text { Formulating } \\
\text { Representing }\end{array}$ & 29.2 & 44.6 & 15.2 & 38.8 & 49.0 & 12.2 \\
\cline { 2 - 7 } $\begin{array}{l}\text { Planning } \\
\text { Executing }\end{array}$ & 63.3 & 29.2 & 17.5 & 55.5 & 26.5 & 18.0 \\
\cline { 2 - 7 } $\begin{array}{l}\text { Monitoring } \\
\text { Reflecting }\end{array}$ & 62.5 & 22.5 & 10.0 & 68.1 & 20.7 & 11.2 \\
\cline { 2 - 7 } & 39.0 & 40.0 & 21.0 & 44.1 & 37.1 & 18.8 \\
\hline
\end{tabular}

The first study was performed at the end of the first half of the year. It was revealed that participants self-evaluated planning, executing, and representing as their best abilities, while formulating, reflecting, monitoring, and exploring were 
self-evaluated as somewhat worse. Rating of monitoring and reflecting abilities as "excellent" improved after the second half of the year. This qualitative conclusion was checked quantitative with the help of Freedman test for dependent samples. The differences in the evaluation abilities of problem solving and other problem solving abilities (representing, planning and executing) were statistically significant (Table 4). The results did not support positive changes to self-evaluation scores of monitoring and reflecting abilities after the second half of the year. We might assume that longer projects were necessary but there may be other reasons.

Table 4. The differences between pre-service science teachers self-evaluation of problem solving abilities (Freedman test)in the second diagnostic study

\begin{tabular}{|l|l|l|}
\hline Problem solving competence & Monitoring & Reflecting \\
\hline Exploring & 0.101 & 0.059 \\
\cline { 2 - 3 } Understanding & 0.066 & 0.072 \\
\hline Formulating & 0.085 & 0.098 \\
\cline { 2 - 3 } Representing & $0.044^{*}$ & $0.035^{*}$ \\
\hline Planning & $0.000^{*}$ & $0.000^{*}$ \\
\cline { 2 - 3 } Executing & $0.023^{*}$ & $0.018^{*}$ \\
\hline
\end{tabular}

The results of the quantitative study supported the conclusions of the qualitative study regarding problem-solving abilities. The latter research revealed that pre-service teachers experienced difficulties in problem solving (scientific inquiry): ,Each of our projects is a small problem that is necessary to solve. Finding solutions to the problem are the most difficult parts, while practice and technique play secondary roles. It is more difficult to decide what to do, not how to do".

The results of the quantitative study showed that only one third $(29.2 \%)$ of the respondents ranked their ability to formulate hypotheses, and organise and critically evaluate information as excellent, whilst a much higher percentage $(67.5 \%)$ of the respondents ranked their planning abilities as excellent.

Self-evaluation of cross-curricular problem solving was, therefore, an intricate and complex task: „Self-evaluation of cross-curricular projects is possible only while working in a group of students studying different science subjects. It is necessary to discuss and help each other in order to achieve common agreement on evaluation ".

Learning through cooperation facilitated the self-evaluation of problem solving by pre-service teachers studying different science subjects. Individual self-evaluation of cross-curricular problem solving was not an easy task as participants lacked appropriate knowledge of other science subjects. 


\section{Conclusions}

1. Problem solving as cognitive processing is directed at transforming a given situation into a goal-oriented situation. Cross-curricular problems often involve multiple goals and seeking to achieve them makes favourable conditions for the application of knowledge in new situations. The shift of knowledge from one subject to another changes the character of activities, and encourages the acquisition of new information or discovering new aspects of knowledge already acquired. Solving cross-curricular problems encourages the application of the main elements of IBST: problem solving (scientific inquiry), 'hands-on' activities, customized learning, argumentation scaffolding, and metacognitive scaffolding.

2. PBL, when based on cross-curricular content, creates suitable conditions for reaching higher levels of problem solving abilities: planning and executing solutions that involve a relatively high number of steps; understanding information through a variety of familiar or unfamiliar representations; dealing with situations that involve many variables and/or where there is high dependency between variables; handling unanticipated obstacles.

3. Finding solution to cross-curricular problems is a specific 'given' component. It is necessary to refer to individual experience of a particular subject while solving cross-curricular problems. Pre-service science teachers know the content of one science subject well but there may be a lack of knowledge regarding other science subjects. Therefore, the aim of solving cross-curricular problems is to analyse an object or phenomenon from the point of view of different science subjects, and then gaps between the 'givens' and 'goals' appear. These gaps can be reduced through cooperative learning. Educating teachers of biology, chemistry or physics through cooperative learning should be an important component of science didactics.

4. Solving of cross-curricular problems in cooperation reveals new aspects of evaluation and self-evaluation abilities. Individual evaluation of solving cross-curricular problems is not sufficiently objective, and pre-service teachers studying only one science subject are unable to self-evaluate the results of cross-curricular problem solving, as they lack knowledge and abilities of other science subjects. Cooperative learning enhances the selfevaluation of cross-curricular problem solving by paying attention to decisions of those studying a different science subject.

Acknowledgements. This work was supported by the EU Seventh Framework Programme project "Science-Teacher Education Advanced Methods (S-TEAM)" No. SIS-CT-2009234870 . 


\section{References}

Anthony, W. S. (1973). Learning to discover rules by discovery. Journal of Educational Psychology, 64, 325-328.

Banchi, H., \& Bell, R. (2008). The Many Levels of Inquiry. Science and Children, 46(2), 2629.

Barnes J. (2011). Cross-curricular learning. 2nd edition. London: Sage Publication.

Blech, C., \& Funke, J. (2010). You cannot have your cake and eat it, too: How induced goal conflicts affect complex problem solving. Open Psychology Journal, 3, 42-53.

Boud, D., Keogh, R., \& Walker, D. (Eds.). (1985). Reflection: Turning experience into learning. London: Kogan Page.

Brousseau, G. (1997). Theory of didactical situations in mathematics. Kluwer Academic Publishers, Dordrecht.

Brown, V.A., Harris, J.A. and Russell, J.Y. (2010). Tackling Wicked Problems: Through the Transdisciplinary Imagination. London: Earthscan.

EC (2010). Communication from the Commission. Europe 2020. A strategy for smart, sustainable and inclusive growth. Downloaded fromhttp://eurlex.europa.eu/LexUriServ/ LexUriServ.do?uri=COM:2010:2020:FIN:EN:PDF

Dewey, J. (1925). Experience and Nature. Chicago-London.

Dewey, J. (1929). The Quest for Certainty. Scanningcenter: Osmania University.

Duncker, K. (1945). On problem solving. Psychological Monographs 58, No. 270.

Edelson, D. (2001). Learning-for-Use: A Framework for the Design of Technology-Supported inquiry Activities. Journal of Research in Science Teaching 38(3), 355-385.

Florida R., \& Tinagli, I. (2004). Europe in the Creative Age. Carnegie Mellon Software Industry Center.

Foldevi, M. (1995). Implementation and evaluation of problem-based learning in general practice. Linköping University Medical Dissertations No. 473. Linköping, Sweden.

Foldevi, M., Sommansson, G., \& Trell, E. (1994). Problem based medical education in general practice: experience from Linkoping, Sweden. British Journal of General Practice, 44/387, 473-476.

Frensch, P., \& Funke, J. (1995). Complex Problem Solving: The European Perspective. Hillsdale, NJ: Lawrence Erlbaum.

Funke, J. (1993). Microworlds Based on Linear Equation Systems: A New Approach to Complex Problem Solving and Experimental Results. In G. Strube, K.-F. Wender (Eds.) The Cognitive Psychology of Knowledge (pp. 313-330). Amsterdam.

Greiff, S. \& Funke, J. (2008). What makes a problem complex? Factors determining difficulty in dynamic situations and implications for diagnosing complex problem solving competence. In J. Zumbach, N. Schwartz, T. Seufert \& L. Kester (Eds.), Beyond knowledge: The legacy of competence. Meaningful computer-based learning environments (pp. 199-200). Heidelberg: Springer.

Keebaugh, A., Darrow, L. Tan, D. \& Jamerson, H. (2009). Scaffolding the Science: Problem Based Strategies for Teaching Interdisciplinary Undergraduate Research Methods. International Journal of Teaching and Learning in Higher Education, 21(1), 118-126.

Kim, M.C., Hannafin, M. J. \& Bryan, L. A. (2007). Technology-enhanced inquiry tools in science education: an emerging pedagogical framework for classroom practice. Science Education, 91(6), 1010-1030.

Kirschner, P. A., Sweller, J. \& Clark, R. E. (2006). „Why minimal guidance during instruction does not work: an analysis of the failure of constructivist, discovery, problem-based, experiential, and inquiry-based teaching". Educational Psychologist 41 (2), 75-86. 


\section{SOCIETY. INTEGRATION. EDUCATION. Volume I}

Klahr, D., Triona, L.M. \& Williams, C. (2007). Hands on What? The Relative Effectiveness of Physical Versus Virtual Materials in an Engineering Design Project by Middle School Children. Journal of Research in Science teaching, 44/1, 183-203.

Mayer, R. (2006). The role of domain Knowledge in Creative Problem Solving. In J.C. Kaufman, J. Baer (Eds.), Creativity and Reason in Cognitive Development (pp. 145185). Cambridge.

Mayer, R. E., \& Wittrock, R. C. (2006). Problem solving. In P. A. Alexander \& P. H. Winne (Eds.), Handbook of educational psychology (2nd ed., pp. 287-304). Mahwah, NJ: Erlbaum.

Papert, S. (1980). Mindstorms: Children, computers, and powerful ideas. New York: Basic Books.

Patton, M. Q. (2002). Qualitative research \& evaluation methods. Thousand Oaks (Calif.) [etc.] : Sage Publications.

PISA 2012 field trial problem solving framework. (2010). Downloaded from http://www.oecd.org/dataoecd/8/42/46962005.pdf

PISA. (2003). Problem solving for tomorrow's world - first measures of cross curricular competencies from PISA 2003. Downloaded from http://www.oecd.org/ dataoecd/25/12/34009000.pdf

Reeff, J. P., Zabal, A. \& Blech, Ch. (2006). The Evaluation of Problem-Solving Competencies. A draft version of a general framework. Downloaded from http://www.die-bonn.de/esprid/dokumente/doc-2006/reeff06_01.pdf

Schmidt, H. G. (1983). Problem-based learning: Rationale and description. Medical Education, 17/1, 11-16.

Scott, K. S. (2014). A Multilevel Analysis of Problem-Based Learning Design Characteristics. Interdisciplinary Journal of Problem-Based Learning, 8(2). Downloaded from http://dx.doi.org/10.7771/1541-5015.1420.

Steffe, L., \& Gale, J. (Eds.). (1995). Constructivism in education. Hillsdale, NJ: Lawrence Erlbaum Associates, Inc.

Van Joolingen, W. R., de Jong, T., \& Dimitrakopoulou, A. (2007). Issues in computer supported inquiry learning in science. Journal of Computers Assisted Learning, 23(2), 111-119.

Zion, M. (2008). On line forums as a 'rescue net' in an open inquiry process. International Journal of science and mathematics education, 6/2, 351-375. 